\title{
STUDI KOMPARASI PENGGUNAAN STIMULANSIA \\ SISTEM CAIR DAN GAS GUNA PENINGKATAN \\ PRODUKTIVITAS TANAMAN KARET \\ DI PT PERKEBUNAN NUSANTARA IX JAWA TENGAH
}

\author{
S. T. Riyadi ${ }^{1}$, S. Anwar ${ }^{2}$ dan W. Roessali ${ }^{2}$ \\ ${ }^{1}$ Program Studi Magister Agribisnis, Program Pascasarjana \\ ${ }^{1}$ PT. Perkebunan Nusantara Cabang Cilacap, Jawa Tengah \\ ${ }^{2}$ Fakultas Peternakan dan Pertanian Universitas Diponegoro \\ email: sept4y4di@gmail.com \\ Diterima: 30 Juli 2017, disetujui: 30 September 2017
}

\begin{abstract}
ABSTRAK
Penghalang utama dalam pengembangan karet alam (Hevea brasiliensis) adalah tingkat produktivitas lahan karet yang masih rendah. Produktivitas tanaman sangat dipengaruhi oleh umur tanaman. Tujuan penelitian ini adalah untuk menganalisis perbandingan produktivitas karet alam dengan penggunaan teknologi stimulant cair dengan stimulant gas dan menganalisis kelayakan finansial penerapan teknologi pada tanaman karet. Lokasi penelitian ditentukan secara purposive di Kebun Kawung, Kabupaten Cilacap seluas 94,5 ha dengan penggunaan stimulansia gas dan penggunaan stimulansia cair pada kebun di Balong Kabupaten Jepara seluas 80,7 ha. Data teknis dan ekonomi merupakan data dalam kurun waktu Januari sampai dengan Desember 2016. Analisis uji beda dilakukan pada produksi dan produktivitas lahan karet dan analisis kelayakan finansial meliputi payback period, net $\mathrm{B} / \mathrm{C}$, NPV dan IRR. Hasil penelitian menunjukkan produktivitas lahan dan produktivitas per penyadap sistem stimulansia gas (Latene) nyata lebih tinggi daripada sistem stimulansia cair (scrapping). Hasil analisis kelayakan finansial eksploitasi karet per ha menunjukkan nilai NPV sistem scrapping lebih rendah dibandingkan system gas, Nilai IRR sistem scrapping (42.48\%) lebih tinggi dibandingkan dengan system gas (22,91\%). Net B/C Ratio pada sistem scrapping menunjukkan nilai yang sama sebesar 2,39. Pengembalian dana investasi diperlukan waktu (payback period) 11 hari pada sistem scrapping lebih pendek dibandingkan sistem gas yaitu 3 bulan 9 hari. Secara finansial penggunaan teknologi stimulan gasmenghasilkan pendapatan lebih tinggi dibandingkan stimulan cair pada tingkat bunga $15 \%$.
\end{abstract}

Kata kunci: gas, finansial, karet, scrapping, stimulansia

\section{ABSTRACT}

The main barrier to the develop of natural rubber (Hevea brasiliensis) is the low rubber productivity level. The productivity of the plant is strongly influenced by the age of the plant. The purpose of this study was to analyze the ratio of productivity of natural rubber with the use of liquid stimulant technology (scrapping) with the Latene gas stimulant and to analyze the financial feasibility of using the technology. The location of the research was determined purposively in Kawung Garden in Cilacap Regency with 94,5 ha with the use of gas stimulant and the use of liquid stimulant at the garden in Balong in Jepara Regency of 80.7 ha. Technical and economic data were collected from January to December 2016. Different test analysis was conducted on rubber production, and productivity, and financial feasibility analysis including payback period, net B / C, NPV, and IRR. The results showed the productivity of land and productivity per tappers of the Latene gas stimulant system was significantly higher than that of the liquid stimulant system (scrapping). The result of financial feasibility analysis of rubber exploitation per ha showed NPV value of scrapping system was lower than the gas system, IRR 
value of scrapping system (42.48\%) was higher than gas system (22.91\%). Net B / C Ratio in the scrapping system showed the same value of 2.39. For the return of investment funds required (payback period) 11 days on the scrapping system, it was shorter than the gas system was 3 months and 9 days. Financially the use of gas stimulant technology was higher than liquid stimulant at $15 \%$ interest rate.

Keywords: finance, gas, rubber, scrapping, stimulant

\section{PENDAHULUAN}

Tanaman karet jenis Hevea brasilliensis Muell Arg adalah tanaman bergetah, dinamakan demikian karena golongan ini mempunyai jaringan tanaman yang banyak mengandung getah (lateks) dan getah tersebut mengalir keluar apabila jaringan tanaman terluka. Karet alam merupakan salah satu komoditas petanian yang penting untuk Indonesia dan lingkup internasional. Karet merupakan salah satu hasil pertanian yang banyak menunjang perekonomian di Indonesia. Hasil devisa yang diperoleh dari karet cukup besar. Komoditas ini dibudidayakan relatif lebih lama daripada komoditas perkebunan lainnya. Tanaman karet diintroduksi pada tahun 1864, dalam kurun waktu sekitar 150 tahun sejak area perkebunan di Indonesia, sebesar 84,5\% adalah milik perkebunan rakyat, sebesar $8,4 \%$ milik swasta, dan hanya $7,1 \%$ merupakan milik negara (Setiawan dan Andoko, 2008)

Tanaman karet diambil lateksnya dengan penyadapan. Penyadapan (eksploitasi) tanaman karet adalah suatu teknik memanen tanaman karet sehingga memperoleh hasil karet maksimal sesuai dengan kapasitas produksi tanaman dalam siklus ekonomi yang direncanakan. Menyadap tanaman karet ibarat kegiatan membuka kran, sedangkan banyaknya produksi tergantung pada kapasitas produksi tanaman (Boerhendhy dan Amypalupy, 2010). Puncak produksi dicapai pada tahun sadap ke-7 sampai ke-10, tetapi produksi cepat merosot hingga mencapai titik terendah pada tahun sadap ke-15. Produksi lateks kemudian bertahan pada tingkat yang stabil sampai menjelang peremajaan (Sumarmadji et al. 2005).

Selain pemupukan, produktivitas tanaman karet dapat ditingkatkan dengan teknologi stimunlasia. Faktor pendorong yang membuat cepat meluasnya penggunaan stimulansia ini adalah karena pengaruhnya yang sangat efektif dalam meningkatkan produksi lateks (Santoso, 1993) dan pohon karet memiliki umur produksi hingga 30 tahun (Indraty, 2002). Keluarnya lateks juga di pengaruhi oleh sistem sadap dan cara sadap yang benar dan teknologi berupa stimulansia. Stimulansia berupa gas etilen yang berfungsi untuk menunda menutupnya pembuluh lateks sehingga lateks yang keluar lebih lama.

Ada 2 (dua) macam jenis stimulansia, yaitu cair dan gas. Stimulansia cair dilakukan dengan cara dioleskan sedangkan stimulansia gas dilakukan dengan melukai kulit pohon sebagai jalan untuk memasukkan stimulansia gas ke pembuluh lateks. Stimulansia gas lebih efektif dalam hal penggunaannya daripada stimulansia cair yang dilakukan dengan cara scrapping. Stimulansia gas dapat digunakan dengan cara sekali pengisian botol dan dapat digunakan untuk waktu 3 bulan dan hemat dalam penggunaan tenaga. Proses stimulansia cair diaplikasikan sebulan 2 (dua) kali dan harus dicampur dengan air serta membutuhkan tenaga kerja yang lebih banyak (Siregar et al., 2013). Teknologi stimulan gas memberikan alternatif untuk mengoptimalkan potensi produksi tanaman (Junaidi et al., 2014).

Penyadap menjadi faktor yang sangat 
menentukan dalam hal peraihan produksi. Program stimulansia gas yang sebelumnya diperlukan 2 penyadap maka sekarang hanya perlu 1 penyadap saja. Perubahan jumlah tenaga kerja ini tentu saja mempengaruhi komposisi biaya produksi yang meliputi biaya tenaga kerja maupun biaya untuk pembelian stimulansia gas sehingga dapat mempengaruhi pendapatan penyadap (Setiawan dan Andoko, 2008). Oleh sebab itu, diperlukan kajian mendalam untuk mengetahui kelayakan finansial produktivitas tanaman karet dengan menggunakan stimulansia gas yang diberikan pada pohon karet tanaman tua ( $>15$ tahun). Hasil-hasil pengujian menunjukkan bahwa stimulan gas memiliki respon positif jika digunakan pada tanaman yang telah dewasa. Penelitian Doungmusik dan Sdoodee (2012) pada tanaman yang lebih dewasa (tanaman berumur 21 tahun) dengan klon yang sama (RRIM 600) diperoleh produksi tertinggi sebesar 137,70 g/p/s. Karyudi et al. (2006) dan Sinamoet al. (2015) menyatakan bahwa dengan memperhatikan efektivitas dan ketahanan tanaman, aplikasi stimulan gas sebaiknya diberikan bila tanaman sudah berumur minimal sekitar 15 tahun sehingga diharapkan terjadi peningkatan dengan penggunaan stimulansia.

Penerapan system stimulansia gas (latene) dilakukan di Kebun Balong Jepara dan Kebun Kawung Cilacap menerapkan system stimulansia cair (scrapping) pada tanaman yang berumur lebih dari 23 tahun. Penelitian ini bertujuan untuk mengetahui tingkat produksi dan produktivitas lahan karet, serta melakukan analisis perbandingan kelayakan finansial tanaman karet dengan menggunakan stimulansia gas dan cair.

\section{METODE PENELITIAN}

Metode penelitian yang digunakan dalam penelitian ini adalah metode deskriptif analitis. Menurut Nazir (2003), penelitian deskriptif ini adalah membuat deskripsi, gambaran atau lukisan secara sistematis, faktual dan akurat mengenai fakta-fakta, sifatsifat serta hubungan antar fenomena yang diselidiki.Lokasi penelitian ditentukan secara purposive adalah PT Perkebunan Nusantara IX Jawa Tengah. Penerapan stimulansia gas (latene) dilakukan di Kebun Balong di Kabupaten Jepara pada area seluas 94,5 ha dan Kebun Kawung di Kabupaten Cilacap dengan luas areal 80,7 ha menerapkan stimulansia cair (scrapping) dengan tanaman yang berumur lebih dari 23 tahun. Perlakuan dilakukan pada wilayah kebun dengan tahun tanam tua yang berumur 23 tahun, dengan alasan bahwa pada usia tersebut produksi mulai menurun.

Data yang dikumpulkan dalam penelitian ini adalah data sekunder berupa laporan produksi, laporan tanaman, laporan biaya maupun laporan manajemen yang diperoleh dari lembaga atau instansi yang terkait dengan penelitian ini. Data yang digunakan adalah data time series tahun 2015. Data meliputi: data jumlah produksi, jumlah hari kerja orang (HKO) panen, HKO pemeliharaan, aplikator, gas-tek, dan zat perangsang.

Untuk mengetahui perbedaan tingkat produksi dan produktivitas lahan karet pada kedua perlakuan dilakukan uji beda (Ghozali (2011). Pendekatan kelayakan finansial yang digunakan meliputi Net Present Value (NPV), Internal Rate of Return (IRR), Net Benefit Cost Ratio (Net B/C Ratio), dan Payback Period. Net Present Value (NPV) atau nilai bersih sekarang dari suatu proyek merupakan nilai sekarang (Present Value - PV) dari selisih antara benefit (manfaat) dengan biaya (cost) pada discount rate tertentu, dihitung dari selisih Total PV Aliran Kas Bersih 
(proceed) - Total PV Investasi (outlays). Apabila evaluasi suatu proyek tertentu telah dinyatakan "layak"maka nilai NPV $\geq 0$, bila $\mathrm{NPV}=0$ berarti proyek tersebut mengembalikan persis sebesar social opportunity cost of capital dan bila NPV $\leq 0$ maka proyek tersebut "tidak layak" atau ditolak artinya ada penggunaan lain yang lebih menguntungkan untuk sumber-sumber yang diperlukan proyek (Sutojo, 2002 dan Husein, 2005).

Net B/C Ratio adalah perbandingan antara jumlah NPV positif dengan jumlah NPV negatif. Hal ini menunjukkan bahwa besarnya benefit berapa kali besarnya biaya dan investasi untuk memperoleh suatu manfaat (Halim, 2005). Net B/C ini menunjukkan gambaran berapa kali lipat manfaat (benefit) yang diperoleh dari biaya (cost) yang dikeluarkan. Apabila net B/C $>1$, maka proyek atau gagasan usaha yang akan didirikan layak untuk dilaksanakan. Demikian pula sebaliknya, apabila net $\mathrm{B} / \mathrm{C}<1$, maka proyek atau gagasan usaha yang akan didirikan tidak layak untuk dilaksanakan. Net $\mathrm{B} / \mathrm{C}$ ratio merupakan manfaat bersih tambahan yang diterima proyek darisetiap 1 satuan biaya yang dikeluarkan.

Internal Rate of Return (IRR) adalah alat ukur kemampuan proyek dalam mengembalikan bunga pinjaman dari lembaga internal keuangan yang membiayai proyek tersebut. IRR memperlihatkan bahwa Present Value (PV) benefit akan sama dengan Present Value $(P V)$ cost. Dengan kata lain, IRR tersebut menunjukkan NPV $=0 . \quad$ IRR dihitung dengan menaikkan Discount Factors (DF) yang merupakan Opportunity Cost of Capital.

$$
I R R=i_{1}+\frac{N P V_{1}}{N P V_{1}+N P V_{2}} X\left(i_{2}-i_{1}\right)(\ldots . .)
$$

Kriteria penilaian IRR adalah jika IRR lebih besar dari tingkat suku bunga yang telah ditetapkan, maka investasi diterima. Sedangkan jika IRR lebih kecil dari tingkat suku bunga yang telah ditetapkan, maka investasi ditolak.

Payback Periods (PP) untuk mengukur seberapa cepat investasi dapat kembali. Jangka waktu pengembalian modal investasi yang akan dibayarkan melalui keuntungan yang diperoleh proyek tersebut. Payback periods dihitung dengan membagi investasi dengan proceed. Semakin cepat waktu pengembalian semakin baik untuk diusahakan (Halim, 2005).

\section{HASIL DAN PEMBAHASAN}

\section{Produktivitas}

Produktivitas dalam penelitian ini dibedakan atas produktivitas lahan dan produktivitas penyadap. Produktivitas lahan merupakan perbandingan jumlah produksi dan luas lahan (Tabel 1). Rata-rata produktivitas lahan pada sistem cair sebesar $1.010 \mathrm{~kg} / \mathrm{ha}$ di Kebun Balong dan pada sistem gas sebesar $1.417 \mathrm{~kg} / \mathrm{ha}$ di Kebun Kawung. Produktivitas per penyadap merupakan hasil bagi jumlah produksi dengan jumlah tenaga ketja selama satu bulan. Rata-rata produktivitas per penyadap selama satu tahun sebesar 6,8kk irisan/hari pada metode cair dan $12,3 \mathrm{kk}$ irisan/hari pada metode gas.

Tabel 1 menunjukkan produktivitas pada sistem gas lebih tinggi $5,5 \mathrm{kk} / \mathrm{hari}$, produktivitas per penyadap dari bulan Januari sampai bulan Mei dengan memakai stimulansia sistem cair ataupun gas terus meningkat. Hal ini adalah ciri khas pada tanaman karet, peningkatan produksi berbanding lurus dengan umur daun. Daun pada tanaman karet menghasilkan karet pada setiap tahun memiliki fase semi, muda, tua dan gugur daun seperti terlihat pada Tabel 2 . Produktivitas terendah pada kisaran bulan Juli sampai September adalah bulan dimana 
Tabel 1. Produktivitas per Penyadap di Kebun Kawung dan Kebun Balong Tahun 2016

\begin{tabular}{lcccccc}
\hline \multirow{2}{*}{$\begin{array}{c}\text { Periode } \\
\text { Tahun 2015 }\end{array}$} & $\begin{array}{c}\text { Jumlah } \\
\text { Pohon }\end{array}$ & Produksi & Irisan & $\begin{array}{c}\text { Jumlah } \\
\text { Pohon }\end{array}$ & Produksi & Iris \\
\hline Januari & (batang) & $(\mathrm{kk})$ & $(\mathrm{kk} / \mathrm{hr})$ & (batang) & $(\mathrm{kk})$ & $(\mathrm{kk} / \mathrm{hr})$ \\
Februari & 19.800 & 6.128 & 6,2 & 20.010 & 8.100 & 9 \\
Maret & 19.800 & 6.570 & 7,1 & 20.010 & 9.240 & 11 \\
April & 19.800 & 7.284 & 7,1 & 20.010 & 11.439 & 12,3 \\
Mei & 19.800 & 8.019 & 8,1 & 20.010 & 13.680 & 15,2 \\
Juni & 19.800 & 8.388 & 8,2 & 20.010 & 16.842 & 18,1 \\
Juli & 19.800 & 6.038 & 6,1 & 20.010 & 8.280 & 9,2 \\
Agustus & 19.800 & 5.524 & 5,4 & 20.010 & 8.472 & 9,1 \\
September & 19.770 & 5.445 & 5,5 & 19.980 & 8.226 & 9,1 \\
Oktober & 19.770 & 5.013 & 4,9 & 19.980 & 8.650 & 9,3 \\
Nopember & 19.761 & 7.920 & 8 & 19.971 & 11.250 & 12,5 \\
Desember & 19.758 & 8.082 & 7,9 & 19.977 & 14.415 & 15,5 \\
\hline Jumlah & 19.756 & 7.069 & 7,1 & 19.971 & 15.300 & 17 \\
\hline Produktivitas & 237.415 & 81.480 & 82,7 & 239.949 & 133.894 & 147,4 \\
\hline Sumber & & $1.010^{*}$ & $6,8 * *$ & & $1.417 *$ & $12,3 * *$ \\
\hline
\end{tabular}

Sumber: PTP IX Jawa Tengah (2016), diolah.

Keterangan: $\mathrm{kk}=\mathrm{kg}$ kering.

*) jumlah produksi/luas lahan, **) jumlah produksi/jumlah penyadap/30 hari

Sistem Cair (Kebun Balong): Luas lahan 80,7 ha, jumlah penyadap 33 orang

Tabel 2. Jumlah Hari Hujan, Curah Hujan dan Fase Daun

\begin{tabular}{lccc}
\hline \multicolumn{1}{c}{ Bulan } & Jumlah Hari Hujan & Curah Hujan & Fase Daun \\
\hline Januari & (hari) & $(\mathrm{mm})$ & \\
Februari & 17 & 280 & Muda \\
Maret & 16 & 340 & Tua \\
April & 14 & 355 & Tua \\
Mei & 15 & 468 & Tua \\
Juni & 17 & 340 & Tua \\
Juli & 3 & 20 & Tua \\
Agustus & 2 & 16 & Gugur daun \\
September & 1 & 4 & Gugur daun \\
Oktober & 1 & 4 & Gugur daun \\
Nopember & 8 & 85 & Semi \\
Desember & 20 & 255 & Semi \\
Jumlah & 17 & 340 & Muda \\
\hline Sumer: Lapran
\end{tabular}

Sumber: Laporan Curah Hujan PTPN IX tahun 2015

Sistem Gas (Kebun Kawung): Luas lahan 94,5 ha, jumlah penyadap 30 orang 
tanaman karet mengalami gugur daun.

Jumlah rata-rata pohon per hanca sistem stimulansia cair 256 pohon, sedangkan jumlah rata-rata pohon per hanca sistem stimulansia gas adalah 260 pohon. Kemampuan menyadap sistem stimulansia gas lebih banyak dari sistem stimulansia cair, ini menunjukkan jumlah Hari Kerja Orang (HKO) untuk menyelesaikan sadapan per satuan luas lebih sedikit pada sistem stimulansia cair. Hal ini akan menyebabkan pengaruh yang besar di masa mendatang, dimana tantangan perkebunan ke depan adalah semakin sulitnya mencari tenaga kerja yang mau bekerja di sektor perkebunan. Antara sistem sadap cair dan gas memiliki perbedaan pada alur sadap yang di iris. Jika akan dibandingkan dengan produksi per pohon setiap kali proses penyadapan pada hasil tabel produktivitas per penyadap maka diperoleh 26,6 kk untuk sistem stimulansia cair dan 47,2 kk untuk sistem stimulansia gas.

\section{Uji Beda Produktivitas Lahan dan Produktivitas per Penyadap}

Berdasarkan Tabel 1 dapat diketahui hasil produksi di kebun Kawung dengan perlakuan stimulansia gas (latene) lebih tinggi dibandingkan kebun Balong dengan stimulansia cair (scrapping). Hasil analisis uji beda dengan paired sample t-test (uji t untuk sampel berpasangan) untuk sistem stimulansia cair dan stimulansia gas diketahui nilai probabilitas atau Sig. (2-tailed) sig. pada level 0,01 artinya terdapat perbedaan yang sangat nyata antara produktivitas lahan sistem stimulansia gas

Tabel 3. Uji Beda Produktivitas lahan dan Penyadap

\begin{tabular}{lcccccc}
\hline \multicolumn{1}{c}{ Uraian } & $\begin{array}{c}\text { Stimulansia Gas } \\
\text { (Latene) }\end{array}$ & $\begin{array}{c}\text { Stimulansia Cair } \\
\text { (Scrapping) }\end{array}$ & t hitung & t tabel & Sign. \\
\hline Produktivitas Lahan & 1417 & 1010 & 6.677 & 0.000 & 0.001 \\
Produktivitas Penyadap & 12.3 & 6.8 & 7.519 & 0.000 & 0.001 \\
\hline
\end{tabular}

Tabel 4. Struktur Penerimaan Hasil Produksi Karet Dengan System Stimulansia Gas dan Cair Tahun 2016

\begin{tabular}{|c|c|c|c|c|}
\hline \multirow{2}{*}{ Bulan } & \multicolumn{2}{|c|}{ Produksi } & \multicolumn{2}{|c|}{ Penerimaan } \\
\hline & Stimulansia Cair & Stimulansia Gas & Stimulansia Cair & Stimulansia Gas \\
\hline & \multicolumn{2}{|c|}{----------(kg/ha) ----------- } & \multicolumn{2}{|c|}{--------- (Rp/ha) ---------- } \\
\hline Januari & 6.128 & 8.1 & 131.445 .600 & 173.745 .000 \\
\hline Februari & 6.57 & 9.24 & 147.825 .000 & 207.900 .000 \\
\hline Maret & 7.284 & 11.439 & 164.618 .400 & 258.521 .400 \\
\hline April & 8.019 & 13.68 & 170.804 .700 & 291.384 .000 \\
\hline Mei & 8.389 & 16.842 & 184.558 .000 & 370.530 .600 \\
\hline Juni & 6.038 & 8.28 & 135.877 .500 & 186.300 .000 \\
\hline Juli & 5.523 & 8.472 & 127.052 .000 & 194.862 .900 \\
\hline Agustus & 5.445 & 8.226 & 117.067 .500 & 176.859 .000 \\
\hline September & 5.013 & 8.65 & 107.779 .500 & 185.953 .500 \\
\hline Oktober & 7.92 & 11.25 & 178.200 .000 & 253.125 .000 \\
\hline Nopember & 8.082 & 14.415 & 181.845 .000 & 324.337 .500 \\
\hline Desember & 7.069 & 15.3 & 155.509 .200 & 336.600 .000 \\
\hline Jumlah & 81.48 & 133.894 & 1.802 .553 .621 & 2.960 .118 .900 \\
\hline
\end{tabular}


(Latene) dengan sistem stimulansia cair (scrapping). Hasil Uji beda dengan metode two tail diperoleh $\mathrm{t}$ hitung 6,677 dan $\mathrm{t}$ tabel 2,200 berarti t hitung $\geq \mathrm{t}$-tabel (5\%) sehingga $\mathrm{H} 0$ ditolak dan $\mathrm{H} 1$ diterima. Jadi produktivitas lahan sistem stimulansia gas Latene lebih tinggi daripada sistem stimulansia cair (scrapping).
Hasil analisis uji beda Tabel 3 terhadap produktivitas per lahan maupun produktivitas per penyadap dengan menggunakan uji paired sample t-test (uji t untuk sampel berpasangan) mempunyai nilai probabilitas atau Sig. (2tailed) menunjukkan sig. 0,01. Hasil ini memberi arti bahwa produktivitas lahan dan produktivitas penyadap baik sistem

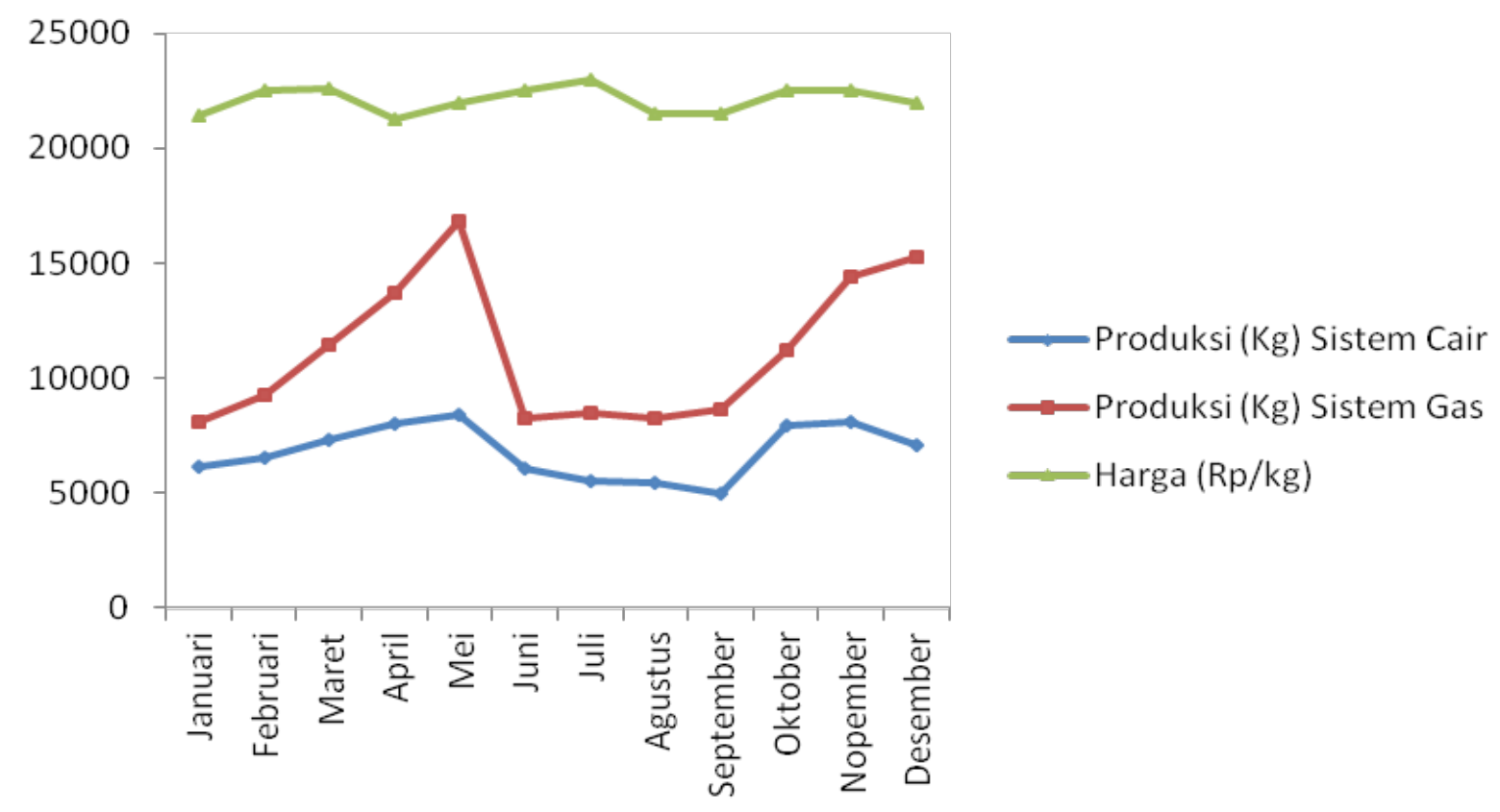

Gambar 1. Perkembangan Produksi dan Harga karet pada Kebun Balong (Gas) dan Kebun Kawung (Cair)

Tabel 5. Struktur Investasi Eksploitasi Karet Sistem Cair dan Sistem gas (Rp/ha)

\begin{tabular}{lcr}
\hline \multicolumn{1}{c}{ Jenis Investasi } & Sistem Cair & Sistem Gas \\
\hline & ---------- & $(\mathrm{Rp} / \mathrm{ha})$ \\
Mangkok Sadap & 324.000 & 384.000 \\
Talang & 35.862 & 31.500 \\
Lakar Sadap & 15.333 & 11.500 \\
Pisau Scraping & 10.667 & - \\
Kuas & 725 & - \\
Ember & 4.000 & - \\
Canester & & 63.000 \\
Aplikator & & 4.725 .000 \\
Staples & & 21.133 \\
Tangga & & 23.625 \\
\hline Jumlah & 390.587 & 5.259 .758 \\
\hline
\end{tabular}

Sumber: Data PT. Perkebunan Nusantara IX (2016) 
stimulansia cair (Scrapping) dan stimulansia Gas (Latene) menunjukkan perbedaan sangat nyata.

\section{Analisis kelayakan finansial}

Struktur penerimaan hasil produksi karet dengan sistem stimulansia gas dan cair Tahun 2016 ditampilkan pada Tabel 3. Tabel 3 menunjukkan harga karet yang berfluktuasi, terjadinya perbedaan harga setiap bulan dipengaruhi oleh jumlah produksi dan kualitas karet yang berubahubah.Berdasarkan Gambar 1 dapat dilihat bahwa pergerakan harga mengikuti kecenderungan jumlah produksi.

Struktur investasi untuk eksploitasi karet pada penerapan sistem stimulansia cair dan stimulansia gas ditampilkan pada Tabel 4. Berdasarkan Tabel 4 diketahui nilai investasi pada sistem stimulansia cair jauh lebih rendah dibandingkan dengan penerapan sistem stimulansia gas. Penggunaan aplikator (alat dan gas) dengan biaya yang sangat tinggi karena peralatan tersebut harus di impor dari Malaysia.

Struktur penerimaan biaya dan pendapatan usaha karet sistem stimulansia cair dan sistem stimulansia gas ditampilkan pada Tabel 5. Berdasarkan Tabel 5 menunjukkan pendapatan pada penggunaan stimulansia gas menunjukkan nilai $64,4 \%$ lebih tinggi dari penggunaan stimulansia cair. Hal ini menunjukkan bahwa penggunaan stimulantsia gas dengan biaya yang tinggi namun dapat menghasilkan produktivitas lahan yang tinggi juga produktivitas per penyadap yang tinggi. Selain itu, penggunaan stimulansia gas dapat menghemat biaya tenaga penyadap seperti ditunjukkan pada Tabel 1 di Kebun Kawung dengan luas 94,5 ha menggunakan tenaga penyadap sebanyak 30 orang dibandingkan di Kebun Balong dengan luas 80,7 ha menggunakan tenaga penyadap sebanyak 33 orang.

Analisis kelayakan finansial yang dilakukan meliputi perhitungan Net Present Value (NPV). Benefit Cost Rasio (BCR). Internal Rate of Return (IRR) dan Payback Period yang merefleksikan tingkat kelayakan eksploitasi setelah dikoreksi dengan tingkat suku bunga deposito 15\% (discount rate).

Tabel 6. Struktur Penerimaan Biaya dan Pendapatan Usaha Karet Sistem Stimulansia Cair Dan Sistem Stimulansia Gas

\begin{tabular}{|c|c|c|}
\hline Biaya & Sistem Cair & Sistem Gas \\
\hline & \multicolumn{2}{|c|}{---------- (Rp/ha/th) ----------- } \\
\hline A. Penerimaan & 1.802 .591 .200 & 2.958 .485 .400 \\
\hline \multicolumn{3}{|l|}{ B. Biaya Tetap } \\
\hline Gaji Penyadap & 3.624 .338 & 2.335 .709 \\
\hline Gaji tenaga Pemeliharaan & 1.482 .990 & 1.482 .990 \\
\hline \multicolumn{3}{|l|}{ C. Biaya Variabel } \\
\hline Premi & 180.000 & 450.000 \\
\hline Lembur minggu & 300.000 & 975.000 \\
\hline Bahan Stimulansia & 227.000 & 472.500 \\
\hline Pasang Mangkok & 23.000 & 23.000 \\
\hline Melakar & 11.500 & 11.500 \\
\hline Isi Staples & & 15.000 \\
\hline Pasang aplikator & & 211.333 \\
\hline Perbaikan aplikator & & 105.667 \\
\hline D. Jumlah Biaya Total $(A+B)$ & 5.848 .828 & 6.082 .699 \\
\hline E. Pendapatan $(E=A-D)$ & 1.796 .704 .793 & 2.954.216.101 \\
\hline
\end{tabular}

Sumber: Data PT. Perkebunan Nusantara IX Kebun Kawung 
Tabel 7. Analisis Finansial Usaha Karet Sistem Stimulansia Cair dan Gas.

\begin{tabular}{lrrc}
\hline \multicolumn{1}{c}{ Indikator } & $\begin{array}{c}\text { Stimulansia } \\
\text { Scrapping }\end{array}$ & Stimulansia Gas & Nilai Batas \\
\hline$N P V(\mathrm{Rp})$ & 9.196 .751 & 11.168 .730 & Nilai Positif \\
$I R R(\%)$ & 42.48 & 22.91 & $>15$ \\
Net $B / C$ Ratio & 2.394 & 2.395 & $>1$ \\
$\begin{array}{l}\text { Payback Periods } \\
\text { (bulan) }\end{array}$ & 0,446 & 3,38 & $<12$ bulan \\
\hline
\end{tabular}

Hasil produksi selama tahun 2016 menghasilkan proceed sebesar Rp 10.211.967 per ha pada sistem stimulansia cair dan Rp 12.772.767/ha sistem stimulansia gas. Net present value dengan tingkat bunga $1,25 \%$ per bulan menghasilkan nilai Rp 9.196.751 per ha (stimulansia cair) dan Rp 11.168.730 per ha (stimulansia gas). Nilai NPV positif maka proyek tersebut layak (feasible) karena menghasilkan lebih banyak kas daripada yang dibutuhkan untuk menutup utang.

Nilai IRR berkaitan dengan kemampuan proyek dalam mengembalikan bunga pinjaman dari lembaga internal keuangan yang membiayai pelaksanaan eksploitasi baik pada sistem cair (scrapping) maupun sistem gas (Latene). Besarnya nilai IRR adalah 42.48 $\%$ (sistem cair) dan $22,91 \%$ (sistem gas), nilai ini lebih besar daripada tingkat diskonto sosial (social discount rate) 15\% yang berarti eksploitasi karet baik sistem cair (scrapping) juga sistem gas (latene) layak untuk dilaksanakan.

Net B/C Ratio pada eksploitasi karet sistem cair (scrapping) dan sistem gas (Latene) adalah 2.39. Nilai ini lebih besar dari 1, berarti setiap $\mathrm{Rp} 1.00$ yang dikeluarkan akan mendapatkan pendapatan sebesar Rp 2.394 (scrapping) dan Rp 2.395 (sistem gas). Pengembalian dana investasi (Payback period), berdasarkan jumlah dana yang dibutuhkan untuk peralatan eksploitasi scrapping dan latene pada Tabel 4 dapat kembali dalam waktu 11 hari sistem stimulansia cair. Hasil ini jauh lebih singkat dibanding sistem stimulansia gas yaitu dalam 3,38 bulan. Hal ini berarti jika usaha dianalisis berdasarkan nilai social discount rate sebesar $15 \%$ maka sistem cair (scrapping) dan sistem gas (Latene) adalah layak. Rendahnya investasi untuk eksploitasi karet sistem ini karena alat-alat yang diperlukan jauh lebih murah. Alat scrapping yang dimaksud berupa pisau untuk mengikis atau mengerok kulit pasir pohon karet yang akan di oles dengan bahan stimulansia. Kuas digunakan untuk mengoles bahan stimulansia ke kulit yang telah dikerok dan ember digunakan sebagai wadah aplikasi stimulansia di lapangan agar lebih mudah pelaksanaannya. Besarnya nilai investasi yang dibutuhkan untuk pengadaan alat meliputi: canister, aplikator gas.mangkok sadap, staples, tangga dan talang sadap serta biaya pembuatan gambar lakar sadap. Nilai terbesar investasi adalah pengadaan aplikator gas yang mencapai porsi $90 \%$ dari investasi. Semua peralatan yang dipakai untuk stimulansia mempunyai umur ekonomis 1 tahun. Teknologi stimulan gas memberikan alternatif untuk mengoptimalkan potensi produksi tanaman (Junaedi et al., 2014).

\section{SIMPULAN DAN SARAN}

Produktivitas lahan karet dan produktivitas per penyadap karet 
menggunakan sistem stimulansia gas (latene) secara signifikan menunjukkan hasil lebih tinggi dibandingkan dengan sistem stimulansia cair (scrapping). Pendapatan usaha karet stimulansia sistem gas sebesar Rp. $\quad 11.168 .730$ lebih tinggi $21.4 \%$ dibandingkan dengan sistem cair Rp. 9.196.751. Analisis finansial pelaksanaan penggunaan stimulansia untuk tanaman karet umur tua ( $>23$ tahun) yang dilakukan oleh PT Perkebunan Nusantara IX baik pada penggunaan stimulansia gas ataupun stimulansia cair di PT Perkebunan Nusantara IX, keduanya adalah feasible. Stimulansia cair dan gas dapat diterapkan pada kebun lain PT Perkebunan Nusantara IX maupun perkebunan Rakyat karena pendapatan (NPV) per hektar per tahun bernilai positif, IRR lebih besar dari tingkat suku bunga yang berlaku, B/C ratio lebih besar dari satu dan payback periode kurang dari satu tahun. Saran yang dapat diberikan berdasarkan hasil penelitian antara lain: penggunaan stimulansia gas dalam skala luas pada tanaman karet yang akan dilakukan peremajaan layak dilanjutkan. Perlu penelitian lebih lanjut untuk melihat tingkat kestabilan produksi dan dampak negatif dari penggunaan stimulansia gas apabila dilaksanakan dalam jangka waktu lama dan pada tanaman karet muda. Mengingat investasi sistem eksploitasi gas yang tinggi hendaknya pemerintah dapat memberikan stimulus kepada perkebunan rakyat yang hampir diremajakan agar diperoleh produksi maksimal.

\section{DAFTAR PUSTAKA}

Boerhendhy, I dan K. Amypalupy. 2010. Optimalisasi produktivitas karet melalui penggunaan bahan tanam, pemeliharaan, sistem eksploitasi dan peremajaan tanaman. Jurnal Litbang Pertanian. 30(1) : 27.
Doungmusik, A dan S. Sdoodee. 2012. Enhancing the latex productivity of Hevea brasiliensis clone RRIM 600 using ethylene stimulation. Journal of Agricultural Technology 8(6): 20332042.

Ghozali, I. 2013. Aplikasi Analisis Multivariate dengan Program IBM SPSS 21 Update PLS Regresi. Badan Penerbit Universitas Diponegoro, Semarang

Halim. 2005. Analisis Investasi. Edisi Kedua Salemba Empat. Jakarta

Hinamo, H., Charloq, Rosmiyati dan Radite. 2015. Respon produksi lateks dalam berbagai waktu aplikasi pada beberapa klon tanaman karet terhadap pemberian berbagai sumber hormon etilen. Jurnal Agroekoteknologi, 3(2) : 542-551.

Husein. 2005. Metode Penelitian Untuk Skripsi dan Tesis Bisnis. Raja Grafindo Persada. Jakarta.

Indraty, I. S. 2002. Perubahan produktivitas dan jaringan panel sadap tanaman karet akibat penggunaan stimulan jangka panjang. Jurnal Penelitian Karet. 20 (1-3): 30-42

Junaidi, J., A. Atminingsih dan T.H.S. Siregar. 2014. Penggunaan stimulan gas etilen pada tanaman karet (Hevea brasiliensis). Warta Perkaretan, 33 (22) : 79-88

Karyudi, Sumarmadji dan E. Bukit. 2006. Penggunaan stimulan gas etilen untuk meningkatkan produktivitas tanaman karet. Prosiding Lokakarya Nasional Budidaya Tanaman Karet 2006. Medan. 4- 6 September. Pusat Penelitian Karet : 198-207.

Nazir, M. 2003. Metode Penelitian. Ghalia Indonesia. Bogor.

PTPN IX Jawa Tengah. 2006. Hubungan Keterkaitan Masak Fase Daun dengan Curah Hujan dan Hari Hujan. PT. Perkebunan Nasional IX Jawa Tengah.

PTPN IX Jawa Tengah. 2015. Perbandingan Produktivitas per Penyadap Antara 
Penggunakan Stimulansia Cair dan Gas. PT. Perkebunan Nasional IX Jawa Tengah.

Santoso, B. 1993. Peranan srimulan etefon dalam penekanan biaya produksi karet dan cara aplikasinya. Warta Perkaretan. 12(2):41-46.

Setiawan, D.H dan A. Andoko. 2008. Petunjuk lengkap budidaya karet. Edisi Revisi. Agromedia Pustaka. Jakarta

Siregar, T. H. S. Junaidi dan Atminingsih. 2013. Alternatif penggunaan stimulan gas etilen dalam optimasi produksi.Makalah pelatihan workshop eksploitasi tanaman karet menuju produktivitas tinggi dan umur ekonomis optimal. Medan. 18 - 21 Maret. Balai Penelitian Sungei Putih. Medan.

Sumarmadji, Karyudi dan T.H.S Siregar. 2006. Rekomendasi Sistem Eksploitasi pada Klon Quick \& Slow Starter serta Penggunaan Irisan Ganda untuk Meningkatkan Produktivitas Tanaman Karet. Pros. Lok. Nas. Budidaya Tanaman Karet. Pusat Penelitian Karet. Medan, 4-6 September. Medan.hlm. 169-188

Sutojo, S. 2002. Studi Kelayakan Proyek, Konsep, Teknik dan Kasus. PT Damar Mulia Pustaka. Jakarta. 